\title{
THE ROLE OF THE SCHOOL COUNSELLOR IN SCHOOL-COMMUNITY COLLABORATION: THE CASE OF SLOVENIA
}

\author{
Dr. Petra Gregorčič Mrvar, University of Ljubljana, Faculty of Arts, Dept. of Educational Sciences, Ljubljana, \\ Slovenia, E-mail: petra.mrvar@ff.uni-lj.si \\ Dr. Jasna Mažgon, University of Ljubljana, Faculty of Arts, Dept. of Educational Sciences, Ljubljana, Slovenia \\ E-mail: jasna.mazgon@ff.uni-lj.si
}

\author{
A R T I C L E I N F O \\ Original Research \\ Received: May, 15.2017. \\ Revised: June, 01.2017. \\ Accepted: Jun, 06.2017. \\ doi:10.5937/IJCRSEE1701019G \\ UDK \\ $37.062(497.4)$ \\ $371.121(497.4)$
}

\section{Keywords:}

school counselling service,

community,

parents, co-ordination,

consultation,

partnership.

\begin{abstract}
A B S T R A C T
The article presents some essential characteristics of collaboration between the school counselling service and individuals or institutions in the community. The role of school counselling in Slovenia is not limited merely to counselling and providing direct assistance to students with learning and their personal development. Rather, it includes the encouragement of all participants in the educational process to create adequate learning environments. The role, however, should also be understood in broader terms as organizational and content collaboration with external environments, institutions and individuals in the community. The authors begin by proposing some starting points for collaboration between the school counselling service and the local community and, in the second part of the article, they move on to the findings of their empirical research study, conducted on a representative sample of school counsellors working in Slovenian primary schools. The results prove the need for collaboration between the school counselling service and different institutions or individuals in the community. The authors primarily focus on examining the obstacles and drawbacks to the collaboration, while they simultaneously highlight examples of good practice that enable constructive collaboration, without which schools and school-based counselling would not be able to contribute to educational processes. The described examples demonstrate that collaboration between schools/school counsellors and institutions/individuals in the community is crucial to solving the problems that students and their families face.
\end{abstract}

(C) 2017 IJCRSEE. All rights reserved.

\section{INTRODUCTION}

Writing on collaboration among schools, parents and the community today and in the past, various authors (e.g. Bryan and Henry, 2008; Bryan and Holcomb-McCoy, 2007; Epstein, 1995; Sheridan et al., 2002; Vidmar, 2015; Walsh and DePaul, 2011) define partnership as cooperation among a number of related individuals/institutions who have common goals and who establish a trustworthy Corresponding Author

Dr. Jasna Mažgon, University of Ljubljana, Faculty of Arts, Dept. of Educational Sciences, Ljubljana, Slovenia, E-mail: jasna.mazgon@ff.uni-lj.si

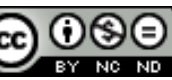

This work is licensed under a Creative Commons Attribution - NonCommercial - NoDerivs 4.0. The article is published with Open Access at www.ijcrsee.com relationship in which they share resources, power and responsibilities. Good-quality collaboration among schools, parents and the community primarily benefits children's (students') development and achievements, but there are also advantages to be gained by parents, teachers, schools and the community as a whole (Epstein, 1995; Sheridan et al., 2002; cf. Thompson, 2012). We have already written on the characteristics and advantages of collaboration among schools, parents and the community elsewhere (see e.g. Kalin et al., 2009; Šteh, Kalin, and Gregorčič Mrvar, 2015). Thus, this article focuses on the role of professional school counselling, which a number of authors (e.g. Bryan and Holcomb-McCoy, 2007; Čačinovič Vogrinčič, 1999; Epstein and Van Voorhis, 2010; Griffin and Steen, 2010; Resman, 1999; Walsh and DePaul, 2011) identify as an important factor in collaboration among schools, parents and the community. 
The first part of the article presents some bases for the collaboration of the school counselling service (In Slovenia the school counselling service is one of the subsystems of a school or preschool, so its primary goal is determined by the primary goal of the school or preschool. Different experts (e.g. pedagogues, psychologists, social workers, social pedagogues, special pedagogues, etc.) work in the school counselling service. It is an interdisciplinary professional school or preschool service) with individuals and institutions in the community. The second part elaborates on the findings of our empirical research study of this collaboration that was conducted among school counsellors in the autumn of 2014.

\subsection{Bases for the collaboration of the school counselling service with individuals and institutions in the community}

According to Resman (Resman, 1999 , pp. 68-69) and Programme guidelines (Programske smernice, 2008.) is a key document serving as a basic orientation/framework for the work of the school counselling service in Slovenia. The document covers all educational subsystems - preschools, primary schools and secondary schools), school counselling as it has been conceptualized in Slovenia was never meant only to assist students in their personal development and learning. Therefore, it provides not only student counselling, directly helping students with their growth and progress, but also indirect help in terms of collaboration on the creation of adequate school environments as well as educational work and processes. This means that when looking after the child's holistic development, it is necessary to look after the conditions for this development, to provide for an adequate physical and social environment. And to be able to do that, school counsellors have to work closely with the school's staff, classes, management, with parents and the external environment (i.e. the community) (ibid.).

Performing three interrelated types of activities, the school counselling service participates in solving complex pedagogical, psychological and social issues in schools concerning everybody attending or working in schools (Programske smernice, 2008). These are activities of assistance, development and prevention and planning and evaluation (ibid., p. 15). Undertaking these three main types of activities, it helps everybody in schools and it collaborates with them in the following areas of everyday life and work in school: learning and teaching; school culture, school climate and order; physical, personal and social development; schooling and career orientation; social and economic difficulties (ibid.). In each of the areas the school counsellor's work includes: work with students, teachers, parents, school management and external institutions. Due to a complex interrelation of pedagogical, psychological and social issues the school counselling service is at its most effective when it incorporates a team of diverse experts. Thus, it is important that counsellors of different professional profiles from different schools cooperate, and that school counsellors also cooperate with experts from relevant external institutions (ibid.).

The school counselling service should, therefore, see beyond the school wall, looking for additional support, assistance and resources in the community, which will primarily benefit the child (the student) as well as others in schools - teachers, school management, parents, etc. (cf. Bryan and Henry, 2008; Bryan and Holcomb-McCoy, 2007; Chen-Hayes, Ockerman, and Mason, 2014; Thompson, 2012; Walsh and DePaul, 2011).

Although school counsellors often cite various obstacles to collaboration with individuals and institutions in the community (e.g. a lot of paperwork, a lack of time, etc.), the majority nevertheless deem school-familycommunity partnerships important and necessary (Bryan and Holcomb-McCoy, 2007; Griffin and Steen, 2010; Kalin et al., 2009).

The levels of the collaboration of school counselling with individuals and institutions in the community

Both schools and school counsellors require collaboration with individuals and institutions in the community, including parents, to be conducted at two levels (Čačinovič Vogrinčič, 1999; Davis, 2014):

1. Collaboration needs to support school work in general, that is, to ensure good-quality educational work as a whole; schools and school counsellors also need collaborators and partners in conducting joint activities, programmes, projects, etc.; sometimes these are group activities, sometimes only individuals are addressed, at other times it is small or big groups from the school or the community, etc. (ibid.); because of educational work as a whole, collaboration has to be established, 
cultivated and maintained wherever it occurs. It cannot be expected that schools will, on their own, be able to meet all the various needs, wishes and expectations expressed by the students and parents entering the school environment. This is particularly relevant in multicultural, democratic societies, in which individuals do not share all values and schools are formally obliged to respect parents' right to such education of their children that does not clash with the parents' religious, philosophical or other beliefs. Teachers and school counsellors are, furthermore, obliged to act educationally so as not to exclude or favour anybody (for more on that see Šebart, 2015). Special attention should be given to those coming from underprivileged social groups or discouraging environments, in which the young are more frequently exposed to risky behaviour (e.g. violence, drug and/or alcohol abuse, etc.) (Bryan and Henry, 2008; Sheridan et al., 2002; Walsh and DePaul, 2011). The task of schools is to act for all students, but especially for the underprivileged, as a protective factor shielding them against risk factors and negative experiences and enable them good-quality educational work (Hočevar, Kovač Šebart, and Mažgon, 2014).

With this in mind school counsellors collaborate with parents, the community (i.e. the student's and family's wider environment) when performing their key activities. They can participate in the collaboration in a variety of ways (Bryan and Holcomb-McCoy, 2007; Davis, 2014; Epstein and Van Voorhis, 2010; Walsh and DePaul, 2011): they can either indirectly circulate or gather information, develop materials, make expert suggestions and recommendations, make referrals outside schools or simply use information for further work with students, parents, teachers and head teachers. Nevertheless, according to the tasks of the school counselling service, school counsellors should act mainly as the initiators of collaboration and cooperation between schools and the community and encourage developing, conducting and evaluating joint collaboration activities.

In their role as initiators of collaboration and cooperation, school counsellors should integrate coordination as a form of schoolbased counselling into their work (cf. Bryan and Holcomb-McCoy, 2007). Coordination is "[...] a process in which school counsellors take the initiative in managing and leading the activities or programmes related to the growth, development, life and work of individuals or groups of students/children" (Resman 1999, p.
71). The role of the coordinator includes the school counsellor's participation in the teams, projects and activities which relate to the training of teachers and parents, and her/his participation in the projects between schools and/or parents and external institutions (ibid.).

2. At the second level both schools and school counsellors require collaboration with individuals and institutions in the community to support the students who need assistance; individuals and institutions in the community are also needed as collaborators and partners in counselling and consultation work when students experience problems and difficulties (e.g. when students cannot work successfully, when teachers cannot guarantee students encouraging environments, when parents can no longer help, etc.) (Čačinovič Vogrinčič, 1999; Davis, 2014). As emphasized by (Čačinovič Vogrinčič, 1999, p. 175), problems can only be solved when they are approached by all those involved.

At this level, school counsellors' work should incorporate a form of consultation, which means "[...] collaborating with 'the third party', with parents, teachers, school management and others whose primary concern is children's/students' well-being and who have an influence on children, and children's work and development are their main focus" (Resman 1999, pp. 70-71). This includes three people (counsellor - consultant, consultee and counselee) with two of them (counsellor - consultant and consultee - the teacher, parents) collaborating in order to help the third (counselee - the student) (Pečjak and Košir, 2012 , p. 70). At the same time, the consultee should be helped to develop self-confidence and to acquire knowledge and skills to work with the counselee - the student (ibid., p. 71).

School counsellors will, namely, face problems which they cannot or are not authorized to solve by themselves. In such cases they may choose to or are forced to contact and cooperate with individuals and institutions in the community or outside the school environment (Davis, 2014; Resman 1999). On the other hand, experts from the community who work with students or their families outside schools may also turn to school counsellors for help, advice or consultation (ibid.).

Resman furthermore emphasizes that the school counselling service and external institutions collaborate as "[...] partners in problemsolving, in which they cannot do one without the other. There should be a rational division of tasks between internal and external forms of counselling and effective complementarity, 
without anyone being subordinated to anyone else [...]" (Resman 1999, p. 79).

The success and efficiency of collaboration will importantly depend, on both the levels, on how the school counselling service manages to present its role and tasks in schools to individuals and institutions in the community and, vice versa, how well they are acquainted with the roles and tasks of external institutions.

The institutions and individuals in the community with whom the school counselling service collaborates

According to Programme guidelines (Programske smernice, 2008, pp. 11-12), the school counselling service cooperates with experts from relevant external institutions in the area of providing assistance to individuals and groups and in the area of development and prevention activities relating to the school as a whole. The service collaborates with counselling centres, hospitals as well as other relevant health institutions and organizations, with social-work centres and other social-care institutions and organizations, with the National Education Institute of the Republic Slovenia, the Employment Service of the Republic of Slovenia, with universities, the Educational Research Institute and various other government and civil-society institutions, organizations and associations. The preschool counselling service is another external collaborator of the school counselling service, and vice versa (ibid., p. 12).

The school counselling service, thus, consults or collaborates with individuals and institutions from a variety of areas, such as education, social care, health care, etc. However, a special position is occupied by collaboration with parents, which is something we have discussed elsewhere (Kalin et al., 2009). It is important for the collaboration to be established already in preschools, when parents and the environment first begin to interact with educational institutions, in which participation and collaboration are of the utmost importance (Hočevar, Kovač Šebart, and Štefanc, 2013).

The initiative to collaborate may come from school counsellors or, as is often the case, from teachers working in schools, from students or parents. On the other hand, the initiative may come from individuals or external institutions themselves as they offer a specific programme or when they need collaboration with schools or school counsellors to be able to help a child or a family better.

Setting up and maintaining collaboration and relationships with individuals and institutions in the community is not (always) easy. It depends on a number of subjective and objective factors, both in schools and in the community and on their interaction. The more schools, individuals and institutions know and understand the characteristics (peculiarities) of one another and develop adequate attitudes towards collaboration, the more successful collaboration is likely to be.

\subsection{The purpose of the research study}

We studied the aspects of school counsellors' collaboration with institutions and individuals in the community in the empirical research study we conducted among primaryschool counsellors in the autumn of 2014 . We approached the issue in the context of providing help and from the aspect of collaboration referring to school/educational work as a whole. Out of a number of research questions, this article focuses on the following two:

1. How do the school counsellors evaluate collaboration with individuals and institutions in the community?

2. What positive and negative experiences have the school counsellors had of collaboration with individuals and institutions in the community?

\section{MATERIALS AND METHODS}

The descriptive and causal non-experimental method was used for the research (Sagadin, 1993).

All primary-schools in Slovenia $(\mathrm{N}=$ 453) were sent a link to the online questionnaire by e-mail in October 2014. The nonrandom sample thus consisted of 196 school counsellors working in Slovenian primary schools, of whom $189(96.4 \%)$ were women and $7(3.6 \%)$ were men. Their average age was 43 years, and their average length of service was 16 years. 91 of them $(46.4 \%)$ worked in urban schools and 105 (53.6\%) worked in non-urban schools. The largest share of the school counsellors in our sample was comprised of pedagogues $(40.8 \%)$, almost a quarter were psychologists $(24.0 \%)$, followed by social workers $(18.9 \%)$ and social pedagogues $(11.2 \%)$ and, with the smallest share, 
special pedagogues $(3.6 \%)$. Three respondents selected "Other", with two of them stating that they had degrees in both pedagogy and psychology.

Half of the counsellors were responsible for the central school and $43.4 \%$ of them were responsible for both the central school and its branch schools. 13 school counsellors selected "Other", eight of whom stated that in addition to their central school they also worked as counsellors in the preschool, and three stated that in addition to the central school they also worked in other schools to reach the full-time employment requirement. A little over a third of the counsellors stated that there was no one else beside them working in the school counselling service, and a little under two thirds of our respondents reported that their school counselling service employed more people.

The questionnaire consisted of evaluation scales with a high degree of reliability, which was tested with the method of internal consistency (Cronbach's coefficient $\alpha$ was $\alpha$ $\geq 0.9$ for all the values). In all the scales the first factor explained more than the presupposed minimum validity requirement of $20 \%$. The questionnaire also included three open questions and two combined questions. In two questions the respondents were asked to rank the given values. The counsellors completed the questionnaire via online application. The data were processed with the SPSS 22.0 software package. The descriptive analysis of variables was used. The open-question answers were divided into categories according to their content similarities.

\section{RESULTS AND DISCUSIONS}

\footnotetext{
The evaluation of collaboration with different institutions in the community

The research shows that the school counsellors collaborated with parents, other primary and secondary schools, preschools, boarding schools and social-work centres the most frequently (on a weekly or monthly basis). The largest share of our respondents collaborated monthly or a couple of times a year with the National Education Institute of the Republic of Slovenia, counselling centres and hospitals. A couple of times a year and on special occasions they collaborated with the Employment Service of the Republic of Slovenia, the Career Centre, the Ministry of Education, Science and Sport, universities, volunteers' associations, the police, specialized institutions for people with special needs and
}

working organizations. On special occasion they also collaborated with other institutions working in the area of education, such as the Educational Research Institute, the Slovenian Institute for Adult Education, the Institute of the Republic of Slovenia for Vocational Education and Training, etc. In the "Other" category the school counsellors listed collaboration with the church or priests, old people's homes, OAP associations, humanitarian organizations, various associations, school inspection and the municipality. These results confirm that school counsellors collaborate with a variety of institutions in the community (cf. Vogrinc and Krek, 2012). Nevertheless, it is to be expected that due to the tasks of the school counselling service school counsellors collaborate with parents the most frequently.

The responding school counsellors evaluated collaboration with external institutions on the following scale: 1 - very poor, 2 - poor, 3 -good, 4 - very good, 5 - n/a. 
Table 1. The school counsellors' evaluation of collaboration with institutions in the community

\begin{tabular}{|c|c|c|c|c|c|c|c|}
\hline $\begin{array}{l}\text { The school counsellors' evaluation of } \\
\text { collaboration with institutions in the } \\
\text { community }\end{array}$ & & 岛 & 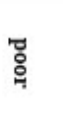 & 。야 & 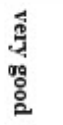 & 롫 & 홀 \\
\hline \multirow{2}{*}{$\begin{array}{l}\text { Employment Service of the Republic of } \\
\text { Slovenia, Career Centre }\end{array}$} & $f$ & 5 & 8 & 104 & 56 & 17 & 190 \\
\hline & $\mathrm{f} \%$ & 2.6 & 4.2 & 54.7 & 29.5 & 8.9 & 100.0 \\
\hline \multirow{2}{*}{$\begin{array}{l}\text { National Education Institute of the Repub- } \\
\text { lic of Slovenia }\end{array}$} & $f$ & $/$ & 4 & 112 & 65 & 8 & 189 \\
\hline & $\mathrm{f} \%$ & I & 2.1 & 59.3 & 34.4 & 4.2 & 100.0 \\
\hline \multirow{2}{*}{ Ministry of Education, Science and Sport } & $f$ & 3 & 20 & 118 & 22 & 26 & 189 \\
\hline & $\mathrm{fo} \%$ & 1.6 & 10.6 & 62.4 & 11.6 & 13.8 & 100.0 \\
\hline \multirow{2}{*}{$\begin{array}{l}\text { Educational Research Institute, Institute for } \\
\text { Adult Education, Institute for Vocational } \\
\text { Education and Training, etc. }\end{array}$} & $f$ & 2 & 10 & 72 & 16 & 89 & 189 \\
\hline & $\mathrm{f} \%$ & 1.1 & 5.3 & 38.1 & 8.5 & 47.1 & 100.0 \\
\hline \multirow{2}{*}{ Social-work centre } & $f$ & I & 23 & 104 & 58 & 3 & 188 \\
\hline & $\mathrm{f} \%$ & 1 & 12.2 & 55.3 & 30.9 & 1.9 & 100.0 \\
\hline \multirow{2}{*}{ Counselling centres } & $f$ & 2 & 9 & 86 & 69 & 23 & 189 \\
\hline & $\mathrm{f} \%$ & 1.1 & 4.8 & 45.5 & 36.5 & 12.2 & 100.0 \\
\hline \multirow{2}{*}{$\begin{array}{l}\text { Hospitals (local hospitals, Clinical Centre, } \\
\text { Paediatric Clinic, etc.) }\end{array}$} & $f$ & I & 5 & 82 & 99 & 4 & 190 \\
\hline & $\mathrm{f} \%$ & 1 & 2.6 & 43.2 & 52.1 & 2.1 & 100.0 \\
\hline \multirow{2}{*}{$\begin{array}{l}\text { Other schools (primary, secondary } \\
\text { schools), preschools, boarding schools }\end{array}$} & $f$ & I & 1 & 46 & 142 & 1 & 190 \\
\hline & $\mathrm{f} \%$ & 1 & 0.5 & 24.2 & 74.7 & 0.5 & 100.0 \\
\hline \multirow{2}{*}{ Universities } & $f$ & 3 & 17 & 63 & 19 & 86 & 188 \\
\hline & $\mathrm{f} \%$ & 1.6 & 9.0 & 33.5 & 10.1 & 45.7 & 100.0 \\
\hline \multirow{2}{*}{$\begin{array}{l}\text { Volunteers' associations, e.g. in the area of } \\
\text { prevention, sport, cultural activities, etc. }\end{array}$} & $f$ & 1 & 4 & 73 & 85 & 26 & 189 \\
\hline & $\mathrm{f} \%$ & 0.5 & 2.1 & 38.6 & 45.0 & 13.8 & 100.0 \\
\hline \multirow{2}{*}{ Parents } & $f$ & I & 1 & 81 & 105 & 2 & 189 \\
\hline & $\mathrm{f} \%$ & 1 & 0.5 & 42.9 & 55.6 & 1.1 & 100.0 \\
\hline \multirow{2}{*}{ The police } & $f$ & I & 1 & 93 & 86 & 10 & 190 \\
\hline & $\mathrm{f} \%$ & 1 & 0.5 & 48.9 & 45.3 & 5.3 & 100.0 \\
\hline \multirow{2}{*}{$\begin{array}{l}\text { Specialized institutions providing help to } \\
\text { children/students with special needs }\end{array}$} & $f$ & I & 5 & 93 & 63 & 28 & 189 \\
\hline & fo $\%$ & 1 & 2.6 & 49.2 & 33.3 & 14.8 & 100.0 \\
\hline \multirow{2}{*}{ Working organizations } & $f$ & 4 & 6 & 71 & 31 & 69 & 181 \\
\hline & $\mathrm{f} \%$ & 2.2 & 3.3 & 39.2 & 17.1 & 38.1 & 100.0 \\
\hline \multirow{2}{*}{ Other } & $f$ & 2 & $/$ & 3 & 3 & 9 & 17 \\
\hline & $\mathrm{fo} \%$ & $\begin{array}{c}11 . \\
8\end{array}$ & / & 17.6 & 17.6 & 52.9 & 100.0 \\
\hline
\end{tabular}

According to our findings, we can assert that the school counsellors were relatively satisfied with their collaboration with different community institutions, since the majority deemed it to be either good or very good. The counsellors evaluated collaboration with other schools, preschools and boarding schools as the best. They hardly ever said collaboration with external institutions was very poor, though some did evaluate it as poor.

The evaluation results suggest an encouraging conclusion, and satisfaction with the existing collaboration certainly provides good bases for further collaboration. It is important for school counsellors to feel that external institutions and individuals are on their side and that they can cooperate with them successfully, as this will make it easier to coordinate the goals and manners of collaboration both at the level of educational work as a whole and at the level of helping students or families with difficulties. The evaluations suggest that the great majority of the school counsellors had had good experiences of collaboration, which is also confirmed by their descriptions presented below.
Descriptions of (positive and negative) experiences that the school counsellors had of collaboration with individuals and institutions in the community

An important aspect of collaboration between school counsellors and individuals or institutions in the community is, certainly, an analysis of past experiences and collaboration. Such analysis enables counsellors to assess the (lack of) success in previous work and collaboration. Therefore, we asked the counsellors to provide an example of a positive and a negative experience of collaboration, which gave us valuable insights into the evaluations provided above.

Such descriptions were provided by 125 school counsellors. We distributed the responses in the following categories (the shares of individual categories are given with reference to the total number of responses concerning a positive experience):

1. The range of various and varied activities provided by schools/school counsellors in collaboration with individuals and institutions in the community (79.2\%): the counsellors 
listed a number of very different and heterogeneous activities, programmes and projects that schools or school counsellors carried out in collaboration with individuals and institutions in the community. We note that these include activities of providing assistance in the context of which school counsellors provide help - through interinstitutional work and collaboration with external institutions and experts - to children (students) or groups of children (students) and parents or families with various problems. At the same these include activities in schools intended for all students, teachers, parents and/or individuals and institutions in the community: for instance, career orientation, prevention activities, sport, culture, nature, technology and health activities, intergenerational integration, educational activities, etc. Regarding the activities in schools intended for all students, the school counsellors most frequently reported career orientation and prevention activities (e.g. in the fields of violence, human trafficking, online safety, use and abuse of drugs, smoking, sexuality, etc.).

2. A positive experience of individual institutions and individuals in the community (68\%): the school counsellors highlighted different institutions or individuals in the community that they had had positive experiences of collaboration with - associations and volunteers' organizations providing prevention activities, sport and culture activities, etc.; other primary and secondary schools; socialwork and crisis centres; hospitals, counselling centres; the police; and numerous other individuals and institutions in the community. Moreover, the respondents emphasized the role of the school counselling service in such collaboration: they believe that within each school the counselling service is the one who collaborates with external services the most.

3. Collaboration or activities intended for a specific group of students, parents or families, teachers or individuals in the community (62.4\%): the counsellors mainly stressed individual students or groups of students who participated in specific activities, programmes or projects. Often, the activities included all students, but the respondents emphasized students with different problems (e.g. emotional, learning, behaviour, etc.), socially underprivileged students and students from poorer social-economic backgrounds, students with special needs, talented students, students who were victims of family violence, students with long-term illnesses, immigrant students and Romani students. This category of responses also includes those in which the school counsellors stressed positive experiences of institutions or individuals in the community when the latter provided teachers and school counsellors with training during (regular weekly) expert meetings covering different issues. The counsellors also mentioned positive experiences that related to providing assistance to parents or families. Finally, we added the examples in which schools carried out activities which contributed to the life and work of individuals or institutions in the community.

4. Positive aspects, benefits, effects and outcomes of good-quality collaboration and joint work (37.6\%): this category includes the responses in which the school counsellors described positive aspects, effects and outcomes of good-quality collaboration on both sides: for schools or students on one side and for external institutions or individuals on the other side. The school counsellors saw benefits for all participants in collaboration in the exchange and constructive confrontation of different opinions; in gaining experience and new information and knowledge about specific issues from different experts; in greater expertise or better-quality professional work; in faster, more efficient and more in-depth collaborative problem-solving; in co-creation; in socializing; in expanding social networks, etc. They named the following among benefits to students and parents: care for the child' wellbeing, support for the students, active spending of free time, support for parents, etc.

5. Teamwork - jointly planning, conducting and evaluating projects and activities - and interinstitutional networks (28\%): the counsellors underlined the importance and efficiency of teamwork in specific one-off activities or yearly projects or programmes. They emphasized that without the help of external institutions or individuals, without teamwork and interinstitutional networks they would not have been able to carry out certain activities or projects and solve students' and families' problems. In certain activities or projects schools, parents and a number of external institutions can collaborate at the same time. Furthermore, the counsellors emphasized the importance of teamwork and interinstitutional networks comprising various external institutions. They stated that certain problems that students or families encountered could only be solved with the help and good-quality participation of external institutions or individuals.

6. The conditions for good-quality collaboration with institutions or individuals from the community $(12 \%)$ : the counsellors 
stressed that good-quality collaboration between schools and institutions or individuals in the community required positive attitudes and specific communicative, organizational and cooperative skills and knowledge.

As can be seen, the counsellors listed among positive experiences both the collaboration with institutions and individuals in the community which refers to counselling and consultation work when helping students or families as well as the collaboration concerning the work of schools (i.e. educational work as a whole) when acting at the level of the school, for instance in career orientation, cultural, sport activities, etc.

Next, we analysed the responses of the responding school counsellors who had gaven a description of a negative experience $(\mathrm{n}=$ 105). We distributed the descriptions in the following categories (here, also, the shares of individual categories are given with reference to the total number of responses concerning a negative experience):

1. Unresponsiveness of external institutions or individuals, rigidity when solving students' or families' problems $(25.7 \%)$ : the responding counsellors stated that external institutions or individuals did not always respond, and they sometimes responded slowly, without interest, desire or engagement to the counsellors' interventions and reporting of problems with students or families. In some cases the counsellors complained about the collaboration in general. Solving students' or families' problems was sometimes slow, rigid, time-consuming, and sometimes the problems were not solved at all. Problem-solving was also not done in multi- or interdisciplinary teams, sometimes the collaboration was merely professed and without active participation. Another problem was the limited authority of certain institutions, which resulted in laying responsibility and blame for the solution of students' or families' problems from one institution onto another. A further problem was the constant fluctuation of staff in some institutions.

2. A lack of time and resources for collaboration (21.9\%): the counsellors maintained that they as well as experts from external institutions frequently lacked sufficient time for collaboration, that they were overloaded with other responsibilities, and that they were pressed for time and found it hard to agree on schedules. Additional responsibilities brought about burnout, great expectations led to hurry, exhaustion, etc. There was also a lack of financial and material resources, which disabled carrying out individual or joint projects. The counsellors had also had negative experience of excessive paperwork needed for collaboration.

3. Inadequate information exchange and communication (17.1\%): some of the counsellors reported rarely or never receiving feedback from external institutions or individuals about a student or family they worked with. They also said that contacts with external institutions or individuals were not always two-way communication - counsellors had to draw up a number of reports, etc., but they received no guidelines or information about the students or families from external institutions or individuals. Finally, the counsellors reported differing views on situations and solutions to problems.

4. Unprofessional conduct and inappropriate attitudes of external institutions or individuals in the community (15.2\%): the counsellors reported occasional unprofessional conduct when solving students' or families' problems, especially relating to confidential information "leaks", giving information to third parties, etc. Some of the counsellors' own safety was jeopardized because of the unprofessional conduct of another institution (counsellors receive no protection in case of danger). The responding counsellors also referred to the superior and arrogant manner and negative attitudes of some individuals or institutions in the community towards schools or individual teachers or school counsellors.

5. Negative experiences of (not) completing agreed activities (5.7\%): individuals or institutions in the community did not finish the activities in schools that had been agreed on, they did not excuse their absences, they imposed limits or demands on schools, their work was not relevant or they were not sufficiently well-prepared.

6. Problems in collaboration with parents $(4.8 \%)$ : this category includes the replies by the responding counsellors that emphasized the negative experiences of working with parents, grandparents or families when addressing students' problems. It also includes the responses which reveal situations in which parents or families no longer wanted to be in contact with the school counsellors after the latter had informed external institutions of a certain issue.

When looking at negative experiences, we can start by assessing as positive the fact that almost a third of the respondents $(24.8 \%)$ reported not having or not remembering any problems when collaborating with external 
institutions or individuals. This is doubtlessly a good starting point for further, good-quality collaboration.

However, when describing negative experiences, the counsellors stressed certain factors which posed obstacles to goodquality collaboration between schools or the school counselling services and the community. They emphasized a lack of time, material and financial resources and excessive bureaucracy, which confirms the findings made by previous evaluations of the school counselling service (Bezić, 2008; Razvoj in spremljanje delovanja mreže svetovalnih služb (Poročilo o RA projektu), 2007). A decrease in certain (administrative) tasks, on the one hand, and adequate conditions and resources (including the legislative level) for collaboration, on the other, would certainly improve collaboration. It seems even more important to ask whether collaboration can be successful if school workers and experts from external institutions are not motivated, if they do not establish good-quality relationships, and if they do not have the competencies required for such collaboration. Here we are faced with the collaboration obstacles and drawbacks that the school counsellors emphasized in our research study: unresponsiveness, inadequate information exchange and communication and unprofessional conduct. It should be emphasized that - in the wish for good-quality collaboration - some fundamental conditions should be guaranteed, which the responding counsellors drew attention to in their descriptions of positive experiences: collaboration participants should develop interpersonal, communicative, cooperative and organizational skills.

\section{CONCLUSIONS}

Our research findings confirm that the school counselling service has an important role in developing the network of collaboration with various individuals and institutions in the community, for example with other schools, preschools, governmental and non-governmental organizations and associations, with cultural and sport institutions, etc. Such networks enable the school counselling service to encourage, promote, develop and coordinate the collaboration activities that bring schools, communities and families together. These are three closely interconnected contexts, affecting each child's development (Epstein, 1995). Together, they can support children's (students') healthy, holistic development.
From the perspective of the three contexts it is important for collaboration between schools and the community (the collaboration program) to reflect individuality, to be unique and special for each individual school, and to take account of the community's characteristics. In addition to the structural aspect of collaboration, the relational aspect ought to be foregrounded: how collaboration and interpersonal relationships are established and what their quality is (Sheridan et al., 2002).

The significance of teamwork should also be stressed (i.e. meaning jointly planning, conducting and evaluating activities), which the counsellors participating in our study explicitly highlighted. This alerts us to the need for the conditions for collaboration, teamwork and problems solving - involving teachers, parents, external institutions and individuals - to be established in schools and in external institutions. This will allow for good-quality educational work in general and with all students.

It is important for both school counsellors and individuals/institutions in the community to establish mutual trust and to encourage the culture of dialogue, listening, agreeing on goals and collaborative tasks, as well as to respect the competencies of all participants. It is also desirable that school counsellors openly evaluate their work or existing ways of establishing and maintaining contacts, relationships and collaboration with individuals and institutions in the community, and use the evaluation to improve, complement or modify their collaboration.

\section{ACKNOWLEDGEMENTS}

The authors acknowledge the financial support from the Slovenian Research Agency (research core funding No. P5-0174 Pedagogical and andragogical studies - Learning and education for a good quality life in community).

\section{Conflict of interests}

Authors declare no conflict of interest. 


\section{REFERENCES}

Bezić, T. (2008). Razvoj in spremljanje delovanja mreže svetovalnih služb [The development and the observation of the operating of the counselling services' net]. Sodobna pedagogika, 59(2), 60-80. http://www.sodobna-pedagogika.net/ arhiv/2008-59125/stevilka-2-april/c12

Bryan, J., \& Henry, L. (2008). Strengths-based partnerships: A school-family-community partnership approach to empowering students. Professional School Counseling, 12(2), 149-156. https://doi. org/10.5330/PSC.n.2010-12.149

Bryan, J., \& Holcomb-McCoy, C. (2007). An examination of school counselor involvement in school-family -community partnerships. Professional School Counseling, 10(5), 441 - 454, https://doi. org/10.5330/prsc. 10.5.f266j386342r57g6

Chen-Hayes, S. F., Ockerman, M. S., \& Mason, E. C. M. (2014). 101 solutions for school counselors and leaders in challenging times. Thousand Oaks, CA: Corwin, https:// doi.org/10.4135/9781483345932

Čačinovič Vogrinčič, G. (1999). Svetovalno delo s starši, svetovalno delo $\mathrm{z}$ družinami [Counseling services for parents, counseling services for families]. In M. Resman, J. Bečaj, T. Bezić, G. Čačinovič Vogrinčič, \& J. Musek, Svetovalno delo $v$ vrtcih,osnovnih in srednjih šolah [Counseling services in preschools, elementary and secondary schools] (pp. 175-191). Ljubljana: Zavod Republike Slovenije za šolstvo.

Davis, T. E. (2014). Exploring school counseling. Cengage Learning. https://goo.gl/OWH4ky

Epstein, J. L. (1995). School/family/community partnerships. Phi delta kappan, 76(9), 701712. http://search.proquest.com/openview 19e3a9e802f80705150dceec414b8ed1c/1 ?pq-origsite $=$ gscholar\&cbl $=41842$

Epstein, J., \& Van Voorhis, F. (2010). School counselors' roles in developing partnerships with families and communities for student success. Professional School Counseling, 14(1), 1-14. https:// doi.org/10.5330/prsc.14.1.m6070358408g9227

Griffin, D., \& Steen, S. (2010). School-family-community partnerships: Applying Epstein's theory of the six types of involvement to school counselor practice. Professional School Counseling, 13(4), 218-226. https://doi.org/10.5330/ PSC.n.2010-13.218

Hočevar, A., Kovač Šebart, M., \& Mažgon, J. (2014). The availability and use of drugs in Slovenian primary schools and in vicinities close to schools. Hrvatska revija za rehabilitacijska istraživanja, 50(1), 26-35. http://hrcak.srce. $\underline{\mathrm{hr} / 124768}$

Hočevar, A., Šebart, M. K., \& Štefanc, D. (2013). Curriculum planning and the concept of participation in the Reggio Emilia pedagogical approach. European Early Childhood Education Research Journal, 21(4), 476-488. https://doi.org/10.1080 /1350293X.2013.845437

Kalin, J., Resman, M., Šteh, B., Mrvar, P., GovekarOkoliš, M., Mažgon, J., \& Zuljan, M. V. (2009). Izzivi in smernice kakovostnega sodelovanja med šolo in starši. [Challenges and guidelines of quality cooperation between school and parents]. Znanstvena založba Filozofske fakultete.

Pečjak, S., \& Košir, K. (2012). Šolsko psihološko svetovanje [Psychology counseling in schools]. Ljubljana: Filozofska fakulteta.

Programske smernice. Svetovalno delo $v$ osnovnih šolah [Program guidelines. Counseling services in primary schools]. (2008). Ljubljana: Zavod Republike Slovenije za šolstvo.

Razvoj in spremljanje delovanja mreže svetovalnih služb (Poročilo o RA projektu) [The development and the observation of the operating of the counselling services' net ( $R A$ project report)]. (2007). Ljubljana: Zavod Republike Slovenije za šolstvo.

Resman, M. (1999). Pojem in karakteristike šolskega svetovanja [The concept and characteristics of school counseling]. In M. Resman, J. Bečaj, T. Bezić, G. Čačinovič Vogrinčič, \& J. Musek, Svetovalno delo $v$ vrtcih, osnovnih in srednjih šolah [Counseling services in preschools, elementary and secondary schools] (pp. 67-84). Ljubljana: Zavod Republike Slovenije za šolstvo.

Sagadin, J. (1993). Poglavja iz metodologije pedagoškega raziskovanja [Selected chapters from methodology of educational research]. Ljubljana: Zavod Republike Slovenije za šolstvo in šport.

Sheridan, S. M., Napolitano, S. A., \& Swearer, S. M. (2002). Best practices in school-community partnerships. In A. Thomas, \& J. Grimes (Eds.), Best practices in school psychology IV (pp. 321336). Bethesda, MD: National Association of School Psychologists.

Šebart, M. K. (2015). How to Evaluate and Judge When the Moral-Educational Dimension of Instruction Is Concerned?. Review of European studies, 7(11), 138-146. http://dx.doi.org/10.5539/res. v7n11p138

Šteh, B., Kalin, J., \& Gregorčič Mrvar, P. (2015). Sodelovanje med osnovnimi šolami in skupnostjo $\mathrm{s}$ primeri dobrih praks [Collaboration between elementary schools and the community with examples of good practice]. Sodobna pedagogika, 66(4), 26-44. http://www.sodobna-pedagogika. net/arhiv/2015-66132/stevilka-4-december/c3

Thompson, R. A. (2012). Professional school counseling. Best practice for working in the schools. New York, London: Routledge. 
Vidmar, T. (2015). Perspectives of relations between school and parents from the middle ages to the reformation. Pedagogika, 120(4), 102-115. https://doi.org/10.15823/p.2015.041

Vogrinc, J., \& Krek, J. (2012). Delovanje svetovalne službe [Functioning of counseling services]. Ljubljana: Pedagoška fakulteta. Retrieved February 12, from http://pefprints.pef.uni-lj.si/1188/1/ Vogrinc Krek Delovanje svetovalne.pdf

Walsh, M. E., \& DePaul, G. (2011). The essential role of school-community partnerships in school counseling. Handbook of school counseling, 765-783. Taylor \& Francis. 